\title{
DEVLOPMENT OF A PLANTING MACHINE USED UNDER SUB SURFACE IRRIGATION SYSTEM
}

\author{
Morad, M.M ${ }^{1}$, M. KH. Afifi ${ }^{1}$, H. M. Hekal ${ }^{2}$ and \\ E.E. Abd- El Aaty ${ }^{2}$
}

ABSTRACT

A Self-propelled planting machine was developed to be suitable for lands in which sub surface drip irrigation system is applied.

The developed machine was investigated during planting corn seeds as a function of change in both sub surface irrigation parameters ( two different lateral line depths and two distances between emitters in the lateral line) and machine operating parameters( three different forward speeds and two distances between plants in the row).

The sub surface drip irrigation system was evaluated in terms of soil moisture content and water distribution uniformity.

The developed planting machine was evaluated comparing with the manual method in terms of emergence ratio, longitudinal dispersion, energy requirements, crop yield and planting cost.

The experimental results reveal to the following:

- for sub surface irrigation parameters:

Lateral line depth of $30 \mathrm{~cm}$ with three emitters per meter were considered optimum values to achieve high uniformity of water distribution and high water use efficiency.

- for machine parameters:

- Machine forward speed of $3.2 \mathrm{~km} / \mathrm{h}$ with $30 \mathrm{~cm}$ distance between plants in the row were prefered to achieve high crop yield and low planting cost.

\section{INTRODUCTION}

$\tau$ $\mathrm{t}$ is evident, that the increase of any crop production in both quantity and quality does not depend only on the improvement of soil and plant conditions, but also largely on using new irrigation systems as well as using improved methods and technology to fulfil the agricultural processes in the correct time and keep down production cost.

1.Agric. Eng. Dept., Fac. of Agric., Zagazig Univi.

2.Soil Conservation Dept., Desert Research Center, Cairo 
The objectives of irrigation management should be shifted from obtaining maximum grain yield per cultivated area to maximum grain yield per unit of water. In other words, the best irrigation system is the system by which water use efficiency is maximized.

The matching of the used water irrigation system and the used agricultural machines is considered an important question to be answered.

From this point of view, in surface drip irrigation system, agricultural machines can be used after separating lateral parts and installing them after finishing the agricultural processes. Inverse in sub surface drip irrigation system, despite of its advantages, it is difficult to use the agricultural machines because all parts of the system are fixed under ground .

For this reason, such care had to be taken to construct, develop and operate special machines to be suitable for the use under sub surface drip irrigation systems, taking into consideration both irrigation system and agricultural machine efficiences.

Bucks (1995) stated that practical experience along with education and training had helped to improve the design and management of microirrigation systems. Emitter clogging continued to be the biggest difficulty. However, the use of better filtration and chemical treatment systems had reduced or solved most of the problems.Crops grown under subsurface drip irrigation might out yield those grown under surface drip . Abdel-Rahman (1996) mentioned that the subsurface irrigation is better than the surface trickle irrigation because:

-System parts are protected from sunlight (ultra violet ray) that increases the parts life.

-The decrease of the moisture on surface layer decreases the infection in ground crops.

-The subsurface trickle irrigation decreases the evaporation from soil with increased water use efficiency along with fertilizing over subsurface trickle irrigation.

- The water use efficiency increases in subsurface irrigation.

- Using subsurface irrigation produces good moisture distribution in the soil profile. 
Karayel and Ozmerzi (2001) stated that variability in the seed spacing with a precision vacuum seeder increased with increasing forward speed. They revealed that forward speed of $1 \mathrm{~m} / \mathrm{s}$ consistently produced a better seed pattern than 1.5 and $2 \mathrm{~m} / \mathrm{s}$ for precision sowing of melon and cucumber seeds.

Gomaa (2003) noticed that, the planting forward speeds had a significant effect on the field capacity as the greatest value of field capacity of about $3.68 \mathrm{fed} / \mathrm{h}$. was obtained under $8.0 \mathrm{~km} / \mathrm{h}$. forward speed for mechanical planter, while it was $3.52 \mathrm{fed} / \mathrm{h}$. at the previous planting forward speed in case of pneumatic planter. Also, the results showed that, the planting forward speed had an inverse effect on field efficiency.

$\mathrm{He}$ also added that, the pneumatic planter gave the highest values of germination ratio of $90.7 \%$ at forward speed of $3.16 \mathrm{~km} / \mathrm{h}$. Mean while the lowest values of total seed losses compared with mechanical planter, which gave germination ratio of $85.72 \%$ at planting forward speed of 3.16 $\mathrm{km} / \mathrm{h}$, and these were remarked under the different levels of planting forward speeds.

Hanson and May (2004) reported that subsurface drip irrigation in finetextured salt-affected soils can increase yield and profit of tomatoes compared to sprinkler irrigation with acceptable levels of soluble solids (mainly due to the soil salinity at these locations). Drip irrigation also can control subsurface drainage to the shallow ground water.

\section{The objectives of the present study are to:}

1- Develop a small scole - self-propelled plantig machine to be suitable for lands in which sub surface irrigation system is applied.

2- Determine some primary irrigation system parameters to improve uniformity of water distribution

3-Optimize some machine operating parameters to improve uniformity of plant distribution.

4- Evaluate the developed machine comparing with the manual planting from the economic point of view.

\section{MATERIALS AND METHODS}

Field experiments were carried out at Ras Sudr Research Station, South Sinai Governorate in 2008 growing season to plant corn ( Triple Hybrid ) variety 
The mechanical analysis of the experimental soil was classified as sandy loam soil (Table .1).

The experimental field area was about $800 \mathrm{~m}^{2}$, divided into two similar plots, each plot is $400 \mathrm{~m}^{2}(25 \times 16 \mathrm{~m})$.

The first plot was planted manualy while the second plot was planted mechanicaly using the developed planting machine. In the two plots, a sub surface drip irrigation system was installed before planting .

Table 1 : Some soil physical properties of the experimental site.

\begin{tabular}{|c|c|c|c|c|c|c|c|c|c|}
\hline \multirow{2}{*}{$\begin{array}{l}\text { Soil } \\
\text { Depth } \\
(\mathrm{cm})\end{array}$} & \multicolumn{4}{|c|}{ Particle size, $\%$} & \multirow{2}{*}{$\begin{array}{c}\text { Textural } \\
\text { Class }\end{array}$} & \multirow{2}{*}{\multicolumn{2}{|c|}{$\begin{array}{cc}\text { Bulk } & \text { Field } \\
\text { Density capacity } \\
\left(\mathrm{g} / \mathrm{cm}^{3}\right) & (\mathrm{V} \%)\end{array}$}} & \multirow{2}{*}{$\begin{array}{c}\text { Permanent } \\
\text { wilting } \\
\text { Point, } \%\end{array}$} & \multirow{2}{*}{$\begin{array}{l}\text { Available } \\
\text { Water, } \%\end{array}$} \\
\hline & $\begin{array}{c}\text { Coarse } \\
\text { sand }\end{array}$ & $\begin{array}{l}\text { Fine } \\
\text { sand }\end{array}$ & Silt & Clay & & & & & \\
\hline $0-20$ & 3.76 & 65.9 & 17.14 & 13.18 & S. L. & 1.45 & 35.12 & 22.33 & 12.79 \\
\hline $20-40$ & 2.17 & 68.1 & 14.63 & 15.07 & S. L. & 1.64 & 20.26 & 6.99 & 13.27 \\
\hline
\end{tabular}

* Sandy Loam.

The following equipment were used in this research:

- Tractor (New Holand) of $80 \mathrm{Hp}(58.8) \mathrm{kW}$.

- Rotary cultivator (Lambordini) made in Turkia 14 hp (9.3)KW.

- Components of sub surface drip irrigation system.

The sub surface drip irrigation system:

The components of sub surface drip irrigation system were as follows:

Main line PE $75 \mathrm{~mm}$ diameter, sub main line 50mm, Lateral line $16 \mathrm{~mm}$ GR - 2 emitter/ m , Lateral line 16mm- GR - 3 emitter/ m , Stopcock $75 \mathrm{~mm} / 3^{\prime \prime}$, Stopcock $50 \mathrm{~mm} / 2 "$, Tee 16mm, Ends line $75 \mathrm{~mm}$, Ends line 50mm, Ends line $16 \mathrm{~mm}$.

The components of sub surface irrigation system and the experimental design are shown in fig. 1

\section{The developed machine}

A rotary cultivator was developed and modified to be a self-propelled planting machine suitable for lands in which sub surface irrigation system is applied.

\section{The developed machine consists of the following parts:}

1- A rotary cultivator: (self-propelled) with an engine of $14 \mathrm{Hp}(9.3) \mathrm{KW}$, Gear box with three forward speeds and one reverse, and Two wheels $14 \times 75$, weight $380 \mathrm{~kg}$. 
2- Hitching point: It is fabricated to join planting unit with the machine frame by small buckles from Iron shaft with $(6 \mathrm{~mm})$ as a thikness and $(120 \mathrm{~cm})$ as a length .3. The planting units: Two planting units (Jone deere) with length $100 \mathrm{~cm}$ and mass $120 \mathrm{~kg}$ were installed in the rotary cultivator.The components of the planting units were as following:

-Grain hopper: A small and simple grain hopper was built from light iron with full capacity of $10 \mathrm{~kg}$. Grain hopper contains an agitator to prevent seeds from shaping a hill above feeding holes. Grain hopper takes a cylinder shape.

-Feeding cells: Two feeding cells were fabricated, so as to give two distances between plants in the same row during the planting operation

-Disk opener: Two disk openers for the two planting units were fabricated from strong iron steel to penetrate soil and reform seeds flutes.

-Fluted wheel: One wheel in every planting unit was used as covering wheel to cover seeds and transmit motion to feeding cells through sprockets.

-Transimission system: motion was transmitted from fluted wheel to the planting units by means of sprockets and chains.

The developed machine is showen in fig 2

\section{Experimental conditions}

-The sub surface drip irrigation system was studied under the following variables:

- Two depths of irrigation lines $(20$ and $30 \mathrm{~cm})$.

- Two number of emiters per meter $(2 / \mathrm{m}$ and $3 / \mathrm{m})$.

-The developed planting machine was studied under the following variables:

- Three different forward speeds $(2.5,3.2$ and $3.88 \mathrm{~km} / \mathrm{h})$

- Two distances between plants in the same row ( 20 and $30 \mathrm{~cm}$ )

In both manual and mechanical planting, the distance between the two rows are kept to be $60 \mathrm{~cm}$ while the planting depth was about $5 \mathrm{~cm}$.

\section{Measurments}

Evaluation of the developed planting machine and the sub surface irrigation system was carried out taking into consideration the following indicators: 


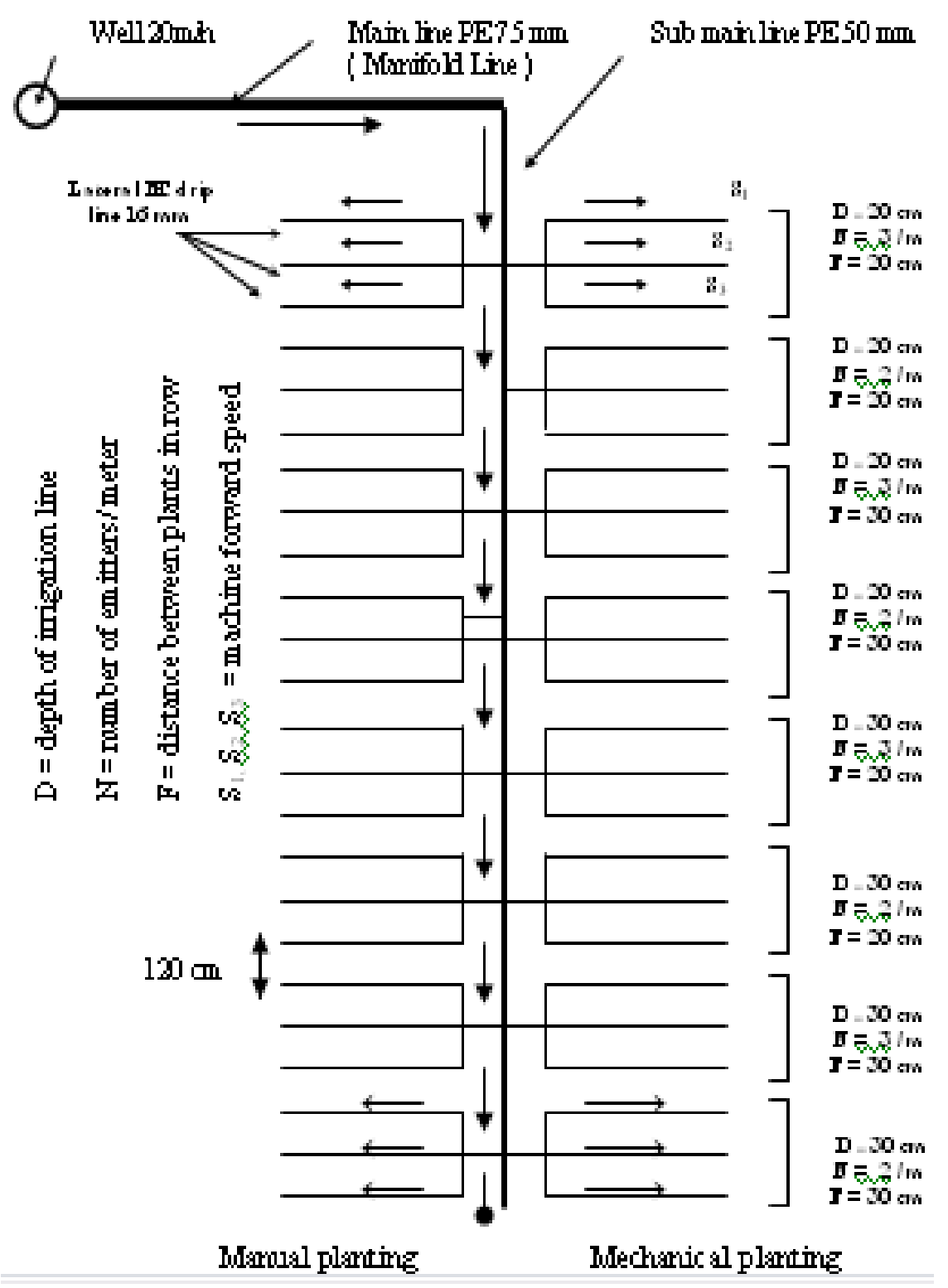

Fig.1 The components of sub surface drip irrigation system and the experimental design. 


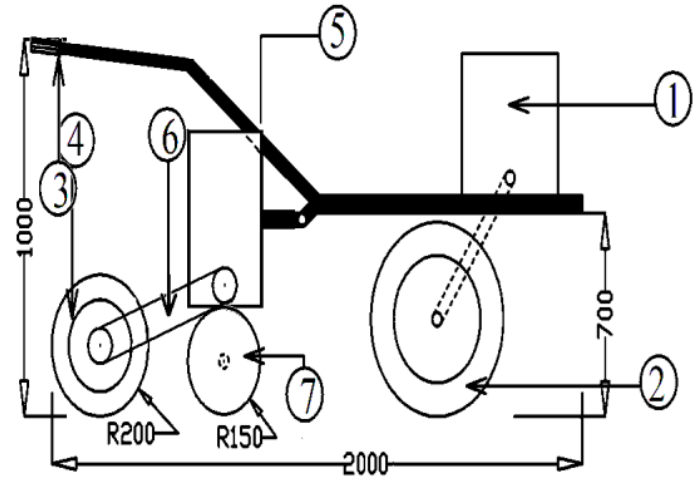

Elevation

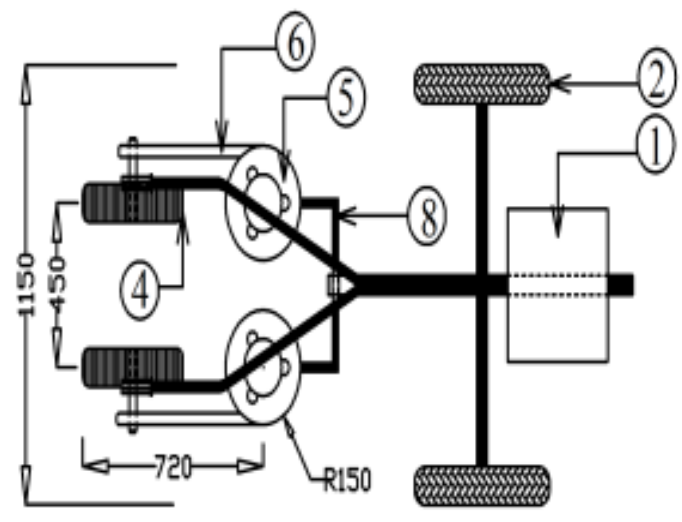

Plan

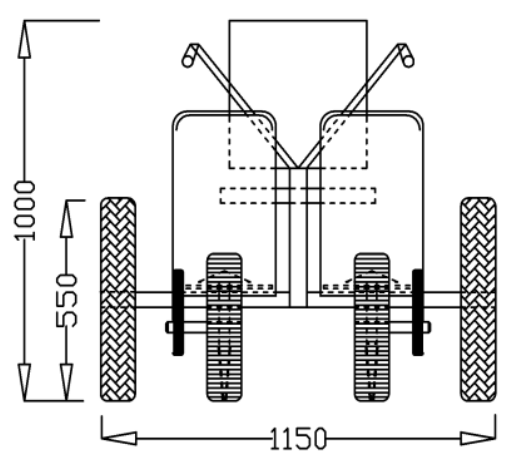

Side View

\begin{tabular}{|c|l|}
\hline $1-$ & Diesel motor \\
\hline $2-$ & Land wheel \\
\hline $3-$ & Direction device \\
\hline $4-$ & Covering wheel \\
\hline $5-$ & Seeds hopper \\
\hline $6-$ & Motion transmission \\
\hline $7-$ & Furrow opener \\
\hline $8-$ & Toolbar \\
\hline
\end{tabular}

(Dimn. In, mm)

Fig 2: Schematic diagram of the developed planting machine. Moisture content:

Measuring of moisture content in every treatment is considered very important to achieve uniformity of water distribution, it is calculated by the following formula:

$$
M C(w . b)=\frac{W w-W d}{W w} \times 100
$$

Where:

$\mathrm{MC}=$ soil moisture content, $\mathrm{W} \%$.

$\mathrm{Ww}=$ wet soil mass, $\mathrm{g}$.

$\mathrm{Wd}=$ dry soil mass, $\mathrm{g}$. 


\section{Water distribution uniformity:}

Water distribution uniformity $(\mathrm{CU} \%)$ is calculated according to the following formula :

$$
C U \%=1-\frac{\sum(X-\bar{X})}{\bar{X} n}
$$

Where,

$\mathrm{CU} \%=$ water distribution uniformity

$\mathrm{X}=$ Moisture content values in roots revealing area $20 \mathrm{~cm}$

$\bar{X}=$ average of Moisture content values

$\mathrm{n} \quad=$ number of soil samples

\section{Emergence ratio :}

The emergence period was estimated, by daily noticing the number of seedling which emerged. When the seedling emergence was grown,the

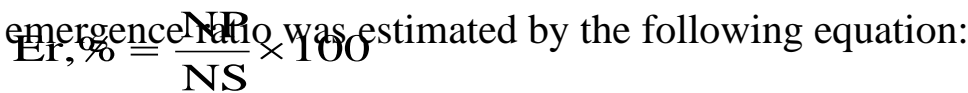

\section{Where :}

$\mathrm{NP}=$ Average seedling number per mentioned area,

$\mathrm{NS}=$ Average number of delivered seeds in the same area.

\section{Plant characteristics :}

Several characteristics were investigated during flowering and harvesting period such as:

- average number of plants in furrow .

- average plant height in $\mathrm{cm}$ (measured from soil surface to the top of main stem )

- average plant diameter .

- average mass of seeds per plant ( calculated as an average of ten plants in grams for each treatments .

\section{Crop yield :}

The corn crop yield was determined for manual and mechanical methods, A number of samples a long the row were taken from different locations for each treatment at random, and then weighted and integrated to determine the average yield of corn per feddan .

\section{Longitudinal and transverse dispersion:}


The dispersion of plants about the center of row is determined according to the following formula (Stell andTorrie, 1980).

$$
\text { Scattering }=\sqrt{\frac{\sum(\mathrm{x}-\mu)^{2}}{\mathrm{~N}}}
$$

\section{Where:-}

$\sum(x-\mu)^{2}=$ The sum of squares of variance of seed scattering

$\mathrm{N}=$ The number of hills

\section{Ground wheel slip :}

Slippage percentage was calculated by using the following equation (Awady, 1992).

$$
\text { Silp } \%=\frac{\text { dis } \tan \text { ce with out load }- \text { dis } \tan \text { ce with load }}{\text { dis } \tan c e \text { with load }} \times 100
$$

\section{Field capacity and field efficiency:}

The field efficiency was calculated by the following formula:

$$
\text { Field efficiency } \%=\frac{\text { Effective field capacity }(\mathrm{fed} / \mathrm{h})}{\text { Theoretical field capacity }(\mathrm{fed} / \mathrm{h})} \times 100
$$

Where:

Effective field capacity is the actual average working rate of area and the theoretical field capacity is calculated by multiplying machine forward speed by the effective working width of the machine.

\section{Fuel consumption :}

Fuel consumption was recorded by accurately measuring the decrease in fuel level in tank immediately after excuting each operation.

\section{The required power:}

The required power $(\mathrm{kW})$ for planting machine was calculated according to Barger et al (1963) by the following formula:

$$
\text { Power }=\mathrm{F} \cdot \rho_{f} \cdot \mathrm{C}_{\mathrm{v}} \cdot \tau_{\mathrm{th}} . \tau_{\mathrm{m}} \cdot \frac{427}{75} \cdot \frac{1}{1.36}, \mathrm{~kW}
$$

\section{Where:-}

$\mathrm{F}=$ Fuel consumption $\mathrm{L} / \mathrm{h}$,

$\rho_{f}=$ Fuel density $(0.85 \mathrm{~kg} / \mathrm{L}$ for diesel fuel $)$,

$\mathrm{C}_{\mathrm{v}}=$ Lower calorific value of fuel $10^{4} \mathrm{kCal} / \mathrm{kg}$,

$\tau_{\text {th }}=$ Thermal efficiency of engine, taken $40 \%$,

$\tau_{\mathrm{m}}=$ Mechanical efficiency of engine, taken $80 \%$. 
427 = Thermo-mechanical equivalent $\mathrm{kg} . \mathrm{m} / \mathrm{kCal}$,

75 = value of $\mathrm{HP}, \mathrm{Kg} \cdot \mathrm{m} / \mathrm{sec}$

\section{Energy requirements}

The energy required for planting operation was calculated by using the following formula:

Energy $=\frac{\text { Power, } \mathrm{kW}}{\text { Effective field capacity fed/h }} \quad \mathrm{kW} . \mathrm{h} / \mathrm{fed}$

\section{Machinary cost analysis :}

The machine cost is determined using the conventional method of estimating both fixed and variable costs .

The planting cost was determined by using the following equation:

Plantig $\cos t=\frac{\text { Machine } \cos t L E / h}{\text { Effective field capacity }(\mathrm{fed} / \mathrm{h})} \quad, \quad$ LE/fed

\section{RESULTS AND DISCUSSION}

The discussion will cover the following main points:

\section{1- Performance evaluation of sub surface drip irrigation system}

1-1.Effect of drip line depth and number of emitters on soil moisture content

Fig. 3 indicate, the effect of drip line depth and number of emitters on soil moisture content. Increasing drip line depth from 20 to $30 \mathrm{~cm}$ under number of emitters of $3 / \mathrm{m}$, caused increasing moisture content from $10.6 \%$ to $13.4 \%$ while at the same increasing in drip line depth under number of emitters of $2 / \mathrm{m}$ caused increasing moisture content from $8.26 \%$ to $9.7 \%$.

The increase in soil moisture content by increasing drip line depth is attributted to the decrease of water losses by evaporation and the effect of sun heat on soil surface. While the increase in soil moisture content by increasing number of emitters in row is due to the increase in water discharge, leaching rate and intensification of moisture content in the soil. 1-2. Effect of drip line depth and number of emitters on water distribution uniformity

Fig.4 show the influence of drip line depth and number of emitters on water distribution uniformity $\mathrm{CU} \%$ in the field, lincreasing irrigation line 
depth from $2 \mathrm{o} \mathrm{cm}$ to $30 \mathrm{~cm}$ under number of emitters of $3 / \mathrm{m}$ increased water distribution uniformity from 84 to $93 \%$, while the same increase in drip line depth under number of emitters of $2 / \mathrm{m}$, increased water distribution uniformity from $81 \%$ to $87 \%$.

The increase of both drip line depth and number of emitters increased water distribution uniformity due to the increase in water keeping period in roots revealing area and decreasing losses of water by evaporation.

\section{2- Performance evaluation of the developed planting machine}

\section{2-1. Effect of machine forward speed on field capacity, field efficiency and ground wheel slip.}

Representative values of field capacity, field efficiency and ground wheel slip versus machine forward speed during planting corn are given in Fig .5

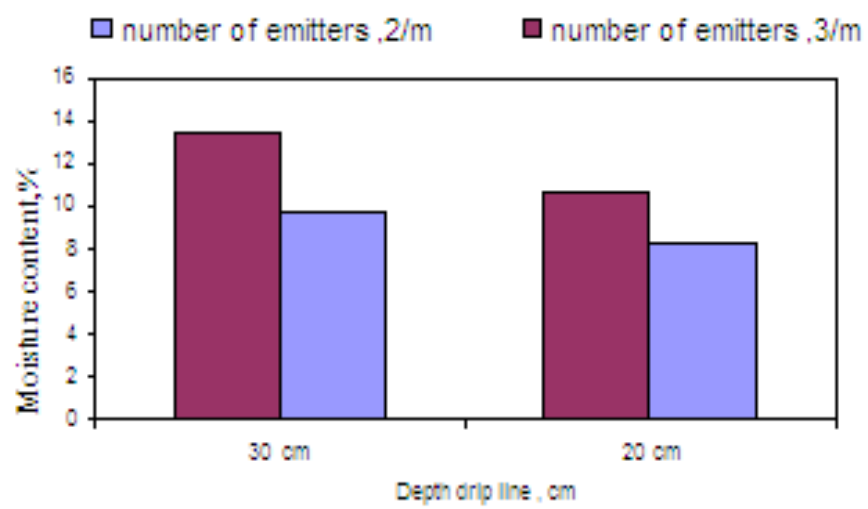

Fig .3 :Effect of drip line depth and number of emitter on soil moisture content

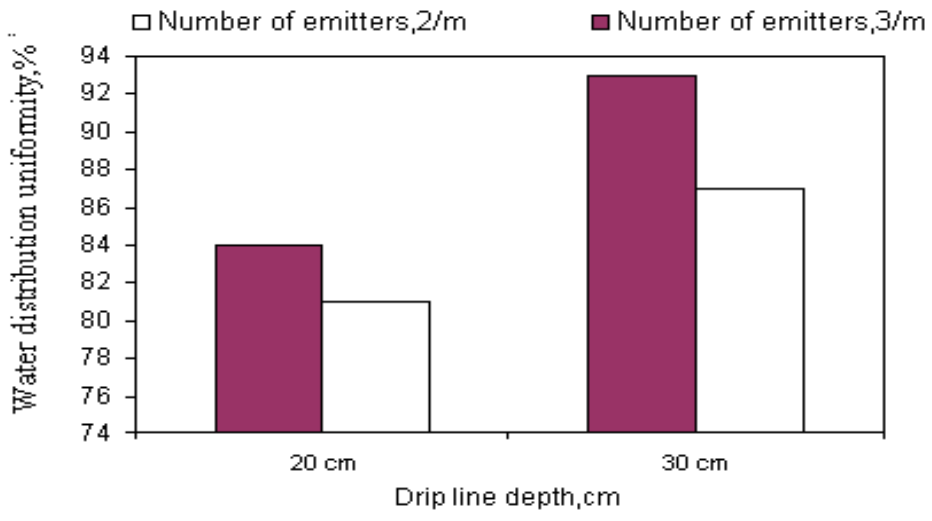

Fig . 4 : Effect of drip line depth and number of emitters on water distribution uniformity 
Results show that increasing machine forward speed from 2.5 to 3.88 $\mathrm{km} / \mathrm{h}$, increased both field capacity from 0.58 to $0.91 \mathrm{fed} / \mathrm{h}$ and ground wheel slip from 4.7 to $9.33 \%$, while decreased the field efficiency from 89.2 to $81 \%$.

The major reason for the reduction in field efficiency by increasing forward speed is due to the less theoretical time consumed in comparison with the other itmes of time losses.

It is obivious that lower forward speed of $2.5 \mathrm{~km} / \mathrm{h}$ tends to increase field capacity, but at the same time, significantly decrease field capacity and the vice versa was noticed with the highest forward speed of $3.88 \mathrm{~km} / \mathrm{h}$. Therefore, Forward speed $3.2 \mathrm{~km} / \mathrm{h}$ is considered the optimum value for the planting operation .

\section{2-2. Effect of machine forward speed on seed dispersion}

Fig.6 show the effect of forward speed on longitudinal and transverse dispersion under two distances between plants in row .Increasing forward speed from 2.5 to $3.88 \mathrm{~km} / \mathrm{h}$, increased longitudinal dispersoin from 2.47 to $2.88 \mathrm{~cm}$ and from $2.66 \mathrm{to} 3 \mathrm{~cm}$ for 20 and $30 \mathrm{~cm}$ distances between plants respectively, also transverse dispersion increased from 8 to $12.12 \mathrm{~cm}$ and from 9.46 to $12.37 \mathrm{~cm}$ unde the same previous conditions. Generally the high forward speeds affect negatively on seed uniformity that tends to cause seed dispersion, because increasing forward speed led to accelerate machine and vibrate it consequently, irregular hills and irregular distances are occurred, thus caused dispersion .

\section{2-3. Effect of machine forward speed on emergence ration}

Fig.7 Show that there are inversely relatioship between machine forward speed and emergence ration, Increasing forward speed from 2.5 to 3.88 $\mathrm{km} / \mathrm{h}$ decreased emergence ratio from 92 to $88.2 \%$ and from 89 to 83.7 $\%$. Under 20 and 30 sm distances between plants in row respectively.

The decrease in emergence ration by increasing forward speed is attributed to the high increase in seed dispersion under high speeds resulting in low emergence ratio.

\section{2-4. Effect of machine forward speed on fuel, power and energy requirements}

Fig. 8 show that both fuel and energy requirements decreased as the forward speed increased while the vice versa was noticed with the 
Required power. Increasing forward speed from 2.5 to $3.88 \mathrm{~km} / \mathrm{h}$ decreased fuel consumption from 1.16 to $1.08 \mathrm{~L} / \mathrm{fed}$ and also decreased energy requirements from 29.1 to $28.79 \mathrm{kw} . \mathrm{h} / \mathrm{fed}$, while the required power increased from 16.88 to $26.2 \mathrm{kw}$.

$\rightarrow$ ground wheel slip $\%$ - - Field efficiency\% - - Field capacity fed/h

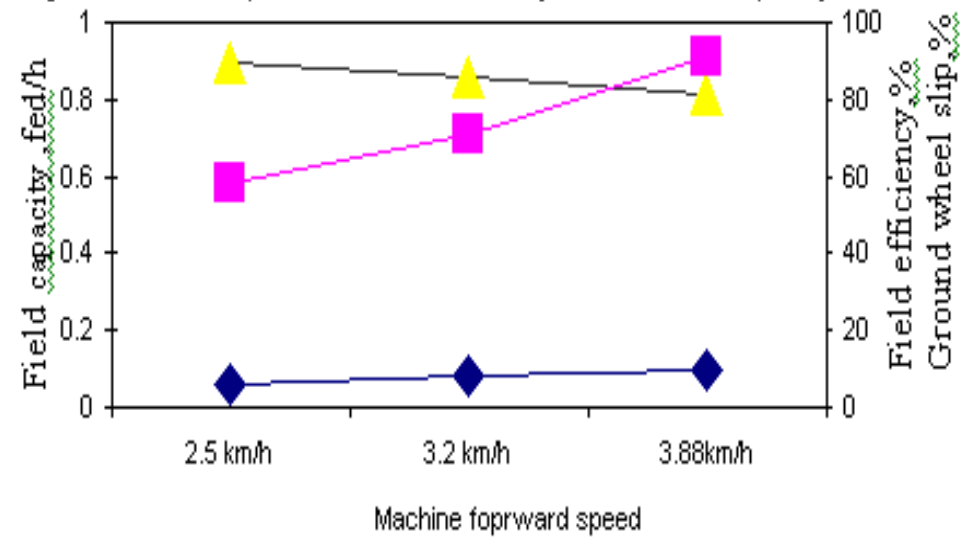

Fig. 5:Effet ofmachine forward speed on field capacity, field efficiency and ground wheel slip.

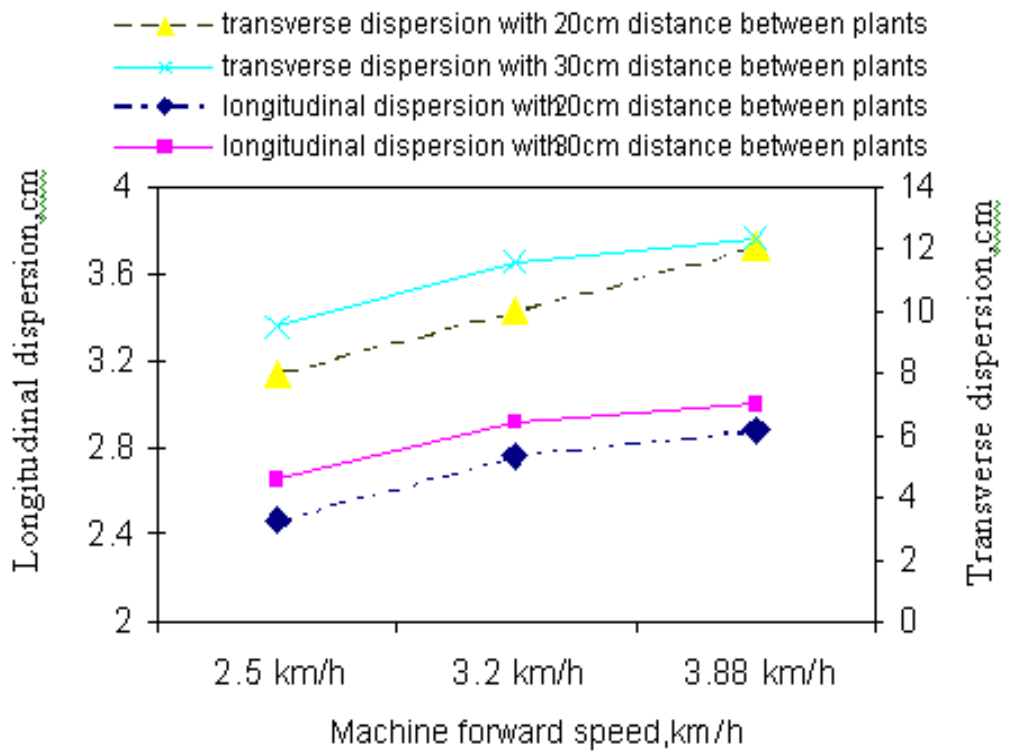

Fig.6 Effect of machine forward speed with distance between plants on longitudinal and transverse dispersion 


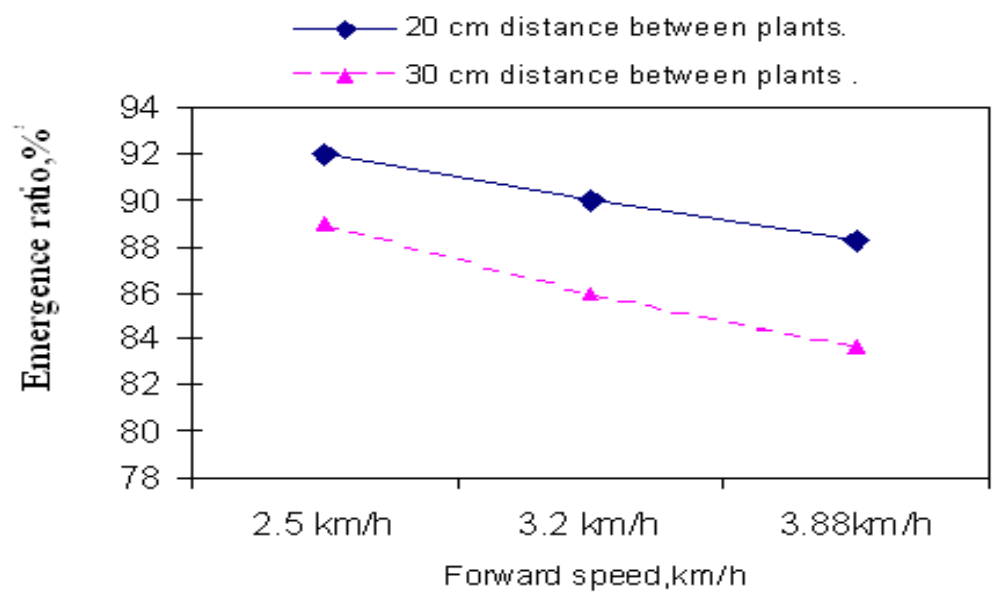

Fig. 7: Effect of machine fonward speed on emergence ratio.

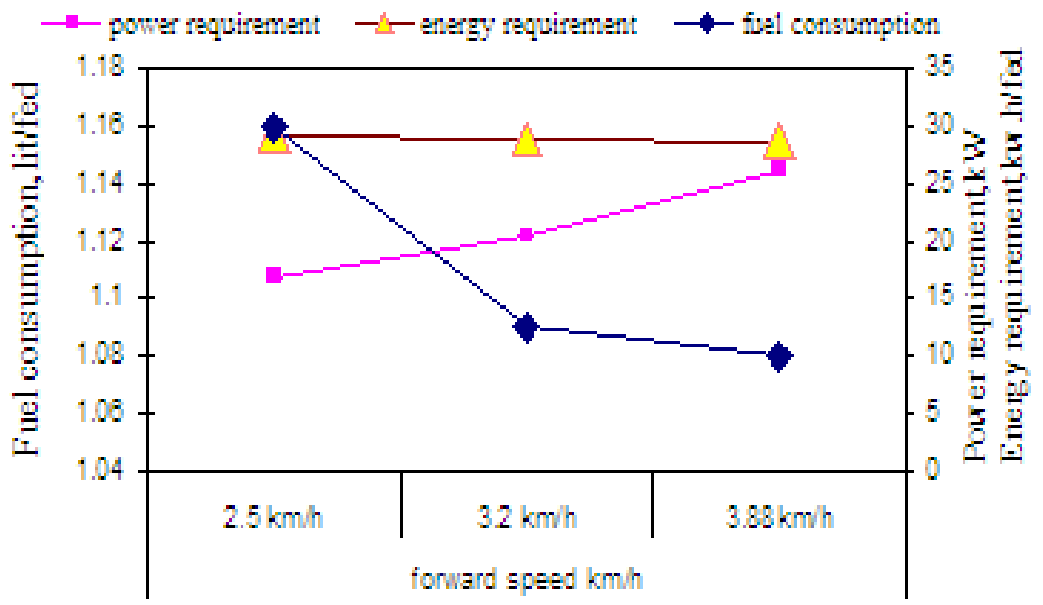

Fig 8: Effect of machine forward speed on fuel consumptiopower and energy requirement.

The decrease of fuel and energy by increasing forward speed is attributed to the increase of field capacity, results in low values of fuel and energy per feddan .

\section{3- Comparison between manual and mechanical planting of corn}

\section{3-1.Effect of planting method on Plant characteristics and crop yield}

(Table. 2) shows the effect of planting method on some Plant characteristics and crop yield, Plant characteristics such as: plant height, plant diameter, and number of seeds per plant as well as crop yield were 
All data show that the mechanical planting method achieved the best results comparing with the manual planting.

The increase in crop yield with the use of mechanical planting comparing with manual planting can be explained as following :

Mechanical planting gave good emergence ratio,good seed distribution, good agricultural depth and healthy corn seedling.

(Table.2) Effect of planting method on Plant characteristics and crop yield

\begin{tabular}{|l|c|c|}
\hline Factors of a comparison & $\begin{array}{c}\text { Mechanical } \\
\text { planting }\end{array}$ & $\begin{array}{c}\text { Manual } \\
\text { planting }\end{array}$ \\
\hline Plant hight, cm & 135 & 118 \\
plant diameter, cm & 2.5 & 1.8 \\
Number of seeds per plant, seed & 451 & 374 \\
Crop yield ,Mg/fed & 3.31 & 2.94 \\
\hline
\end{tabular}

\section{3-2. Effect of planting method on planting costs}

The planting cost values using the developed planting machine were 20.2, 26 and $30.2 \mathrm{LE} /$ fed under forwad speed of $2.5,3.2$ and $3.88 \mathrm{~km} / \mathrm{h}$ respectively, comparing with the highest cost of $72 \mathrm{LE} /$ fed using manual planting by using one farmer for one fedan .

The decrease in planting cost by increasing forward speed is attributed to the increase in machine field capacity.

While the increase in planting cost with the use of manual planting is due to the very low working rate of the farmer.

\section{CONCLUSION}

1- Sub surface drip irrigation system achieved the best results with drip line depth of $30 \mathrm{~cm}$ and number of emitters of $3 / \mathrm{m}$.

2- The developed planting machine achieved high efficiency with sub surface drip irrigation system under forward speed of $3.2 \mathrm{~km} / \mathrm{h}$ and distance between plants of $30 \mathrm{~cm}$

\section{REFERENCES}

Abdel-Rahman, G.A; (1996): The effect of applying drip irrigation system under certain environmental resources on soil productivity deterioration at North Sinai. Miser J.Agric.Eng. 13(2): 612-624 . 
Awady, M.N. (1992) Farm machines. Textbook, Col. of Agric. Ain Shams Univ.; 120 p.

Barger, EL and R. Bainer (1963) : Tractors and their power units., Jon willy and Sons Inc .New York, London U.S.A .

Bucks,D. A.(1995): Historical Developments in Microirrigation. Proceeding in the fifth International Microirrigation Congress. April 2-6, Orlando, florida. ASAE, 2950 Niles Rd., St. Joseph, MI 490859659: 1-5 .

Gomaa, S.M. (2003): Performance evaluation of pneumatic and mechanical planters for cowpea planting. . Misr J. Agric. Eng., 20(4): 965-979.

Hanson and D. May (2004): Effect of subsurface drip irrigation on processing tomato yield, water table depth, soil salinity, and profitability., ,University of California. Agricultural Water Management Pp 1-17.

Karayel D; Ozmerzi A (2001): Effect of forward speed and seed spacing uniformity on a precision vacuum metering unit for melon and cucumber seeds. Journal of Faculty of Agriculture. 14(2): 63-67

Stell, R.G. and S.H. Torrie. (1980). Principles and procedures of statistics. McGraw- Hill Company, N.Y.

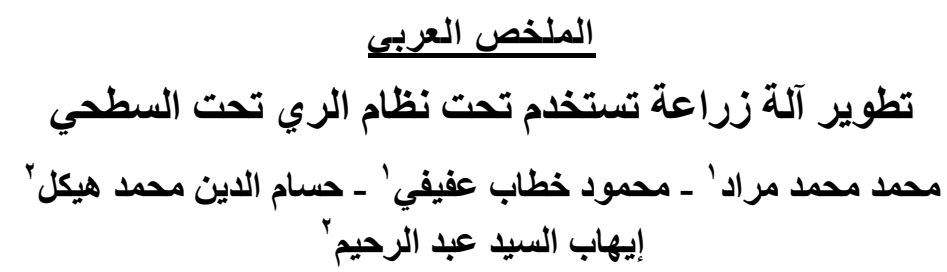

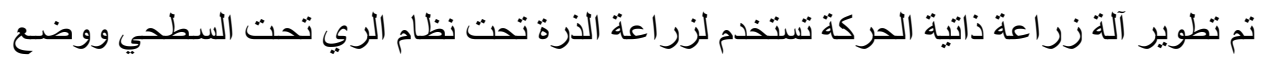

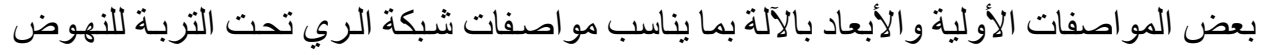

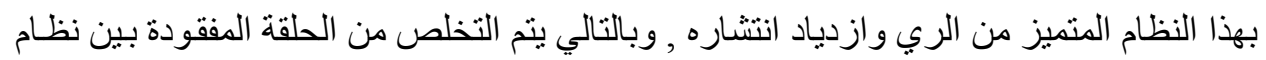

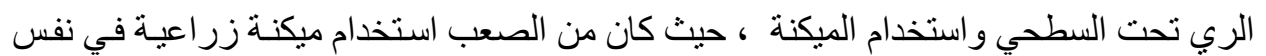
الأرض التي بها نظام ري تحت سطحي قد يعوق استخدام بعض الآلات الزرام العية.

1 ـ قسم الهندسة الزر اعية - كلية الزر اعة - جامعة الزقازيق. r ـ قـسم صيانة الأر اضي- مركز بحوثة الزية الصحر اء. 


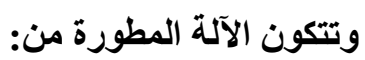

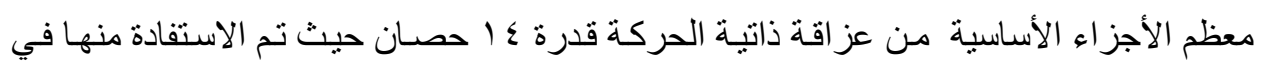

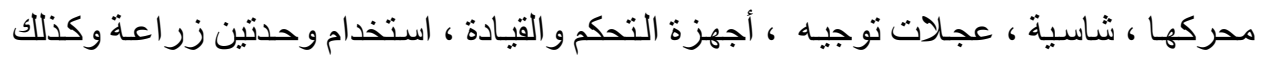
تصنيع خلايا تلقيم. ، تصنيع عمود شبك يحتوى على نقاط شبك. وقد تم إجراء التجارب مع المتغيرات التالية :

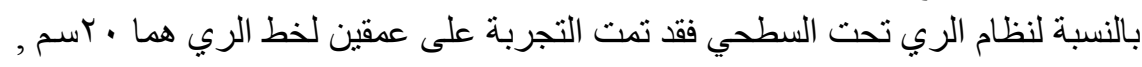

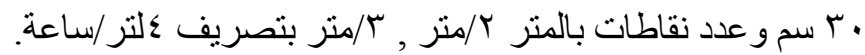

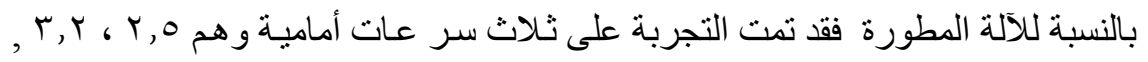

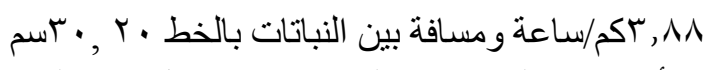

وقد تم تقييم أداء نظام الري تحت السطحي من خلال نسبة الرطوبة وكفة وكفاءة انتظاميـة توزيـع الميـاه

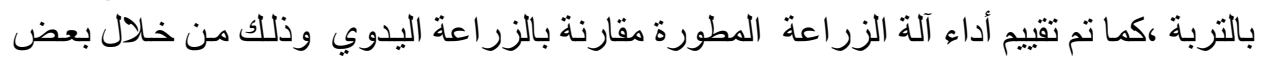

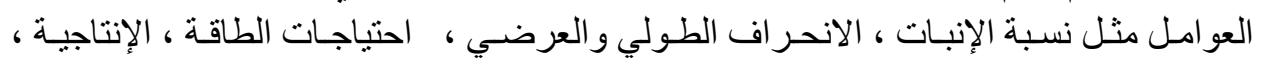

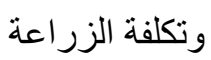
وأظهرت النتائج التجريبية التالمي : في نظام الري تحت سطحي ضبط عمق خط الري على • ساسم مع عدد نقاطات بخط الري

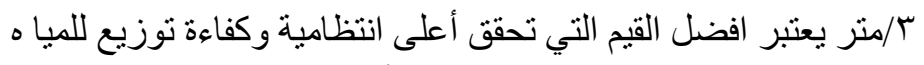

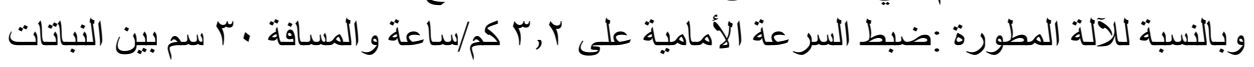
بالصف قد حققت أعلى إنتاجية و اقل تكلفة زر اعة. 